\title{
ПЕРЕДМОВА ДО ПЕРЕКЛАДУ Д. ЮМА «ПРО АКАДЕМІЧНУ, АБО СКЕПТИЧНУ, ФІЛОСОФІЮ»
}

\author{
О.Є. Оліфер
}

\begin{abstract}
Анотація. Ця стаття є передмовою до українського перекладу 12 глави Д. Юма 3 «Дослідження про людське розуміння». Переклад має на меті ознайомити українських читачів з Юмовою філософією. Дванадцята глава рекомендована студентам як першоджерело для аналізу в курсі філософії. Цей переклад відтворює послідовність думок Юма у мовленнєвих конструкціях та пунктуації. Тож, може бути важким для розуміння, особливо для студентів не філософських спеціальностей. Тому до перекладу є передмова, щоб полегшити сприйняття. У передмові висвітлено ключові моменти дванадцятої глави. По-перше, розглянуто історію створення трактату. Подруге, пояснено, чому Д. Юм порівнює скептика з атеїстом. Далі передмова описує два види скептицизму, згадані в перекладеній главі. $€$ такий вид скептицизму, що передує усім наукам і філософії. Він був запропонований Декартом як метод міркування. Другий вид скептицизму є результатом науки та дослідження і походить від античного скептицизму. Юм розглядає його як застарілий тип скептичної філософії, який можна спростувати сучасними ідеями. Далі в передмові викладено юмівський аналіз пірронізму як особливого типу скептицизму. Філософ визнає, що пірронізм - це форма надмірної скептичної філософії, тому її не можна застосовувати на практиці у повсякденному житті. Проте пірронізм корисний, оскільки він дає нам два важливих уроки: філософія повинна піддавати усе сумніву, а людині необхідно розвивати критичне мислення. Заключна частина передмови стосується роздумів Юма про академічну філософію та академічного філософа. Юм розглядає її як сучасний тип пом'якшеного пірронізму, який може бути корисним. Юм стверджує, що академічна філософія може бути надійним методом дослідження. На думку Юма, академічний філософ не вважає, що ясна ідея і твердження, яке легко зрозуміти, неодмінно будуть істинними. Академічний філософ завжди порівнює свої судження 3 накопиченим на практиці досвідом і використовує правила міркувань, прийняті у філософії.
\end{abstract}

Ключові слова: Д. Юм, скептицизм, академічна філософія, пірронізм, досвід.

\section{Preface to the translation of D. Hume's «OF the ACADEMICAL OR SCEPTICAL PHILOSOPHY»}




\begin{abstract}
This article is the preface to the Ukrainian translation of D. Hume's Chapter 12 from «An Enquiry concerning Human Understanding». The translation aims to introduce Humean philosophy to Ukrainian readers. Chapter 12 is recommended as a primary source for the students to analyze in the course of philosophy. The translation follows Hume's sequence of thought in speech patterns and punctuation. So, it can be difficult to understand, especially for non-philosophy students. That is why there is a preface to the translation to make it easier. The preface highlights key points of Chapter 12. Firstly, it outlines the history of the creation of the treatise. Secondly, it explains, why D. Hume compares a sceptic to an atheist. Then, it describes two types of scepticism, mentioned in the translated chapter. There is a type of scepticism, antecedent to all study and philosophy. Descartes introduced it as the method of speculation. The second type of scepticism is consequent to science and enquiry, and it goes back to ancient scepticism. Hume considers it as an old-fashioned type of sceptical philosophy, which can be refuted by modern ideas. After that, the preface outlines Hume's analysis of Pyrronism as a peculiar type of scepticism. The philosopher admits that Pyrronism is a form of excessive sceptical philosophy, so it cannot be turned into practice in everyday life. However, Pyrronism is useful, as it teaches us two essential lessons: philosophy should treat everything with doubts, and a person needs to develop critical thinking. The final part of the preface concerns Hume's speculations on academical philosophy and an academical philosopher. Hume regards it as a modern type of mitigated Pyrronism, which can be useful. Hume argues that academical philosophy can be a reliable method of research. According to Hume, an academical philosopher does not think that a clear idea and a statement easy to understand have to be true. An academical philosopher always compares his judgments with experience, gained in practice, and uses the rules of reasoning adopted in philosophy.
\end{abstract}

Keywords: D. Hume, scepticism, academic philosophy, pyrronism, experience.

Перед вами переклад заключної дванадцятої глави з праці Д. Юма «Дослідження про людське розуміння». Уперше вона була опублікована в 1748 р. у Лондоні під назвою «Філософські есе про людське розуміння» («Philosophical Essays Concerning Human Understanding»). У 1750-1753 рр. цей твір перевидавався як частина чотиритомного збірника праць Д. Юма, що була відома під назвою «Есе і трактати на кілька тем» («Essays and Treaties on Several Subjects»). У 1758 р. вийшло друком чергове перевидання зазначеної збірки філософських праць, але у ньому філософ замінив назву «Філософських есе» на «Дослідження про людське розуміння», під якою ми знаємо цей твір і сьогодні.

Уже під новим заголовком праця пережила кілька повторних видань. Особливо важливі перевидання 1772 і 1777 р. Видання 1772 р. вважається останньою прижиттєвою публікацією, що здійснювалася під керівництвом Д. Юма. Тому вона часто використовується у критичних оглядах. Однак у 1776 р. незадовго до смерті Д. Юм здійснив кілька правок свого твору, що ввійшли у перевидання 1777 р., яке вийшло друком уже після смерті автора. Цей останній варіант часто відтворюють без змін і редакторських правок, тому він зберігає оригінальну орфографію і пунктуацію філософа. Переклад глави виконано 
за оксфордським виданням «Дослідження про людське розуміння». Його редактор П. Міллікан називає своє ставлення до твору філософа дуже «дипломатичним», оскільки ставив собі за мету не створити критичне видання, а точно відтворити твір Юма. ${ }^{1}$ Мета цього перекладу - найточніше передати оригінальний твір, щоб читач мав змогу не тільки ознайомитися зі змістом, але й відчув своєрідний стиль філософствування Юма й зміг краще зрозуміти спосіб міркування епохи англійського Просвітництва.

Дванадцята глава «Про академічну або скептичну філософію» присвячена розгляду скептицизму в його різних варіантах. У попередніх главах Д. Юм висуває скептичні аргументи та доводить їх, використовуючи свій метод. Однак чи можемо ми довіряти цьому методу? Якщо скептицизм як метод буде визнаний ненадійним, тоді вся попередньо зроблена праця філософа зведеться нанівець. Розуміючи це, Д. Юм присвячує окрему главу обгрунтуванню скептицизму, яка складається 3 трьох частин.

Перша частина починається з порівняння скептика та атеїста. Наявна на той час релігійна філософія, що обірунтовувала існування Бога, вважала, що вважати інакше - означає мислити ірраціонально. Скептик, який ставить під сумнів догматичний спосіб мислення релігійної філософії, з її погляду, такий же ірраціональний, як і атеїст. Для Юма важливо показати, що скептицизм грунтується на цілком раціональних засадах. Тому він аналізує історичні форми скептицизму, що існували до нього. Він розглядає два види такого скептицизму: (1) той, що «передує усім наукам і філософіі», (2) той, що «є результатом науки та дослідження». Перший вид скептицизму був запроваджений Декартом і грунтується на методі універсального сумніву. Він дедуктивним шляхом виводить істинні судження від первісного принципу, з певної початкової аксіоми. Проте, на думку Юма, такої аксіоми не існує. Нагадаємо, що у Декарта у якості такого первісного принципу виступало cogito, тобто Я, що існує у мисленні. Проте, на думку Юма, не існує жодної ідеї Я у мисленні. Це всього-на-всього сукупність відчуттів. А тому така сукупність не може розглядатися як надійний принцип, вищий над усіма іншими.

Другий вид скептицизму ставить під сумнів реальність відчуттів. Ця ідея, що розглядалася ще античними скептиками, полягає в тому, що органи чуття недосконалі та що різні фактори довкілля можуть

${ }^{1}$ Hume D. An Enquiry concerning Human Understanding : Edited with an Introduction and Notes by Peter Millican. - Oxford : Oxford University Press, 2007. P. lviii. 
обумовлювати різне сприйняття речі. Тому чуттєвий досвід створює лише подобу речі, яку пізнаємо, а отже, не може гарантувати жодного критерію істинності. Для спростування цієї тези Юм звертається до Локка, який вважає, що відчуття - це форма знань, що містяться у розумі, виведена з одиничних фактів. Хоча Юм і критикував Локка, проте використав його аргумент в обмеженому вигляді для спростування античного скептицизму. Більш «глибокий» аргумент античних скептиків проти достовірності відчуттів Юм розв'язує за допомогою аргументу, запропонованого Дж. Берклі. Цей аргумент Берклі використовує проти Локка і його концепції розрізнення первинних і вторинних якостей речей. Нагадаємо, Дж. Локк намагався пояснити як річ, що існує поза свідомістю, пов'язана з відображенням її у свідомості. Для цього він розвиває ідею про первинні і вторинні якості речей. Первинні якості наявні тільки у речах, вони утворюють сутність речі і породжують у розумі прості ідеї. Вторинні якості містяться у розумі, вони не утворюють сутність певної одиничної речі, а стосуються багатьох речей. Це, наприклад, якість кольору або смаку. Проте, на думку Берклі та Юма, якщо вторинні якості речей існують як певні ідеї розуму, а не містяться в речах, то те ж саме повинно бути істинним і для первинних якостей. Проте яким чином первинні якості постають як ідеї розуму? Первинні якості могли б перетворювати в прості ідеї шляхом абстрагування, але, за Юмом, це дуже сумнівна гіпотеза. Неможливо уявити собі трикутник взагалі, позбавлений певних характерних рис. Тому ідею абстрагування варто відкинути. $\mathrm{y}$ такий спосіб аргумент Берклі, що був запропонований ним проти усіх вільнодумців та скептиків, був використаний Юмом, щоб довести раціональність скептичного методу та переваги над наявним догматичним. Отже, скептицизм, що «є результатом науки та дослідження», постає як занадто гіперболізована й застаріла за мірками Юма форма, оскільки його можна спростувати за допомогою сучасних для філософа аргументів. Проте він не може просто відкинути цей останній вид скептицизму, оскільки той показує необхідність досвіду в пізнанні.

У другій частині Юм розглядає пірронізм як вид скептицизму, через критичні зауваження останнього щодо розумового пізнання. Цей вид скептицизму може стосуватися як абстрактних міркувань, так і розмислів щодо конкретних одиничних фактів з життя. Використання розуму щодо розмислів над абстрактними темами робить його занадто догматичним, що філософ показує на прикладі теологічних розмірковувань щодо простору й часу. Такі відірвані від досвіду міркування здаються ясними та зрозумілими, проте суперечать здоровому глузду. 
Щодо фактів буденного життя, то тут Юм також виокремлює два заперечення щодо очевидності розумового пізнання такого роду фактів. Перше, загальноприйняте заперечення стосується того, що наш розум слабкий у своїх здібностях. Доказом цього є теза про те, що одна і та ж людина або група людей у різному віці, в різних обставинах міркує по-різному стосовно певної теми. Однак ці заперечення проти розуму слабкі з погляду філософії, але їх можна використовувати в буденному житті. Друге філософське заперечення стосується досвіду. Коли ми пізнаємо якийсь факт, покладаючись лише на розум, ми використовуємо причинно-наслідкові зв'язки між попередніми знаннями, але не теперішній досвід. Однак те, що ми у розумі поєднуємо як причину й наслідок певного факту, не обов'язково є ними у буденному житті. Модель, що ми створили у розумі, може суперечити практичній перевірці.

Отже, основна проблема пірронізму в тому, що його неможливо застосувати на практиці в буденному житті. Якщо б усі люди, використовуючи пірронізм, щомиті сумнівалися в усіх своїх розумових здібностях, то просто б не могли далі думати, а отже, і діяти. Тоді б життя повністю припинилося. Для Юма філософія необхідна як принципи та метод повсякденного мислення. Якщо пірронізм не може бути використаний у житті, оскільки він його повністю паралізує, такий скептицизм слід вважати надмірним і відмовитися від нього. Проте це не означає, що пірронізм неправильний як метод або що Юм його повністю відкидає. На його думку, пірронізм треба реконструювати, суттєво обмеживши його з урахуванням розвинутих з часів античності уявлень про пізнання.

Такою формою реконструйованого, осучасненого і обмеженого пірронізму є Юмова скептична або академічна філософія, якій присвячена третя частина глави. Від пірронізму вона запозичує два важливих висновки. По-перше, люди мають схильність впадати в догматизм. Тому філософія повинна ставитися до всього з сумнівом та застереженнями, щоб уникнути цього. По-друге, розум треба використовувати критично, уникати надмірних абстракцій та обмежувати його темами буденного життя, які можна перевірити досвідом. Загалом, Юм характеризує академічну філософію як таку, що може бути «і довготривалою і корисною», яка не дає впасти в надмірний догматизм i виправляє зроблені помилки в міркуваннях досвідом.

Хто такий академічний філософ, на думку Юма? Це людина, що у розмірковуваннях на філософські теми завжди утримується від думки, що з двох тверджень істинним буде те, що здається більш ясним 
і зрозумілим нашому розуму. Також академічний філософ сумнівається у тому, що гарно обгрунтоване судження буде істинним, а менш обгрунтоване судження - хибним, якщо ми лише теоретизуємо, а не звертаємося до практики. Усі судження повинні пройти практичну перевірку: у досвіді з буденного життя або у науковій діяльності. Інакше є загроза впасти в догматизм. Звісно, у доведенні академічний філософ буде користуватися правилами розмірковування, прийнятими у філософії. Проте занадто абстрактні розмисли здатні ввести в оману, тому розмірковування не повинно відриватися від експериментальної перевірки.

Отже, Юм доводить, що тільки академічна філософія може бути дійсно надійним і науковим методом дослідження. А теологія та релігійні метафізичні теорії, що походять від неї, не можуть бути визнані такими. Від них краще відмовитися, оскільки вони не принесуть жодної користі, бо не містять нічого, окрім софістики та ілюзій.

Надійшла до редакиї̈ 31 липня 2020 р.

\section{Оліфер Олена Євгеніївна}

Кафедра філософії

Криворізький державний педагогічний університет

просп. Гагаріна, 54

м. Кривий Ріг

50086

\section{Olifer Olena}

Department of Philosophy

Kryvyi Rih State Pedagogical University

Gagarina ave., 54

Kryvyi Rih

50086

iD https://orcid.org/0000-0002-8837-5514

@ olifer.olena@kdpu.edu.ua

doi) 10.31812 /apd.v0i21.3887 